\title{
Comparative spectrophotometric study of the color stability of three dental porcelains after repeated firings
}

\begin{abstract}
- Marcelo Weber Graduate Program in Oral Diagnosis, Department of Stomatology, School of Dentistry, University of São Paulo, São Paulo, SP, Brazil - Denise Sabbag Haddad Graduate Program in Oral Diagnosis, Department of Stomatology, School of Dentistry, University of São Paulo, São Paulo, SP, Brazil • Marina Gazzano Baladi Graduate Program in Oral Diagnosis, Department of Stomatology, School of Dentistry, University of São Paulo, São Paulo, SP, Brazil • Emiko Saito Arita Discipline of Oral Radiology, Department of Stomatology, School of Dentistry, University of São Paulo, São Paulo, SP, Brazil
\end{abstract}

ABSTRACT || The purpose of this investigation was to quantify the color differences in CIE $\Delta \mathrm{E}$ units produced by multiple firings of three all-ceramic systems used in the fabrication of prosthodontic teeth. Thirty samples of the following brands were fabricated: AllCeram, Noritake Cerabien CZR and Vita VM7. A spectrophotometer was used for reflectance measurement of color after 1 firing, 3 firings, 5 firings and 10 firings. The results were converted into CIELAB units. Color differences $(\Delta \mathrm{E})$ were calculated in the CIE color space. The color differences resulting from multiple firings proved to be dependent on the number of firings and on the porcelain brand tested.

DESCRIPTORS || Tooth, Artificial; Dental Porcelain; Dental Prosthesis; Spectrophotometry; Color.

RESUMO | Estudo espectrofotométrico comparativo da estabilidade de cor de três porcelanas dentais após queimas consecutivas - O objetivo deste estudo foi avaliar a estabilidade de cor de três marcas comerciais de porcelanas dentais aluminizadas durante seu processo de queima. Essas porcelanas são utilizadas para a confecção de dentes de prótese fixa. Para o experimento foram confeccionados 30 corpos-de-prova em forma de disco com $2 \mathrm{~mm}$ de espessura e $10 \mathrm{~mm}$ de circunferência, sendo 10 da marca AllCeram, 10 da marca Noritake Cerabien CZR e 10 da marca Vita VM7. As amostras foram queimadas 10 vezes. As leituras de cor foram feitas em espectrofotômetro de reflexão nos seguintes intervalos: após a $1^{\mathrm{a}}$ queima, após a $3^{\mathrm{a}}$ queima, após a $5^{\mathrm{a}}$ queima e após a $10^{\mathrm{a}}$ queima. As curvas de reflexão foram convertidas em valores LAB e a diferença de cor foi medida por meio do método CIELAB $(\Delta \mathrm{E})$. Os resultados obtidos demonstraram que existe variação de cor e que essa variação depende do número de queimas realizadas e da marca comercial utilizada.

DESCRITORES | Dente Artificial; Porcelana Dentária; Prótese Dentária; Espectrofotometria; Cor.

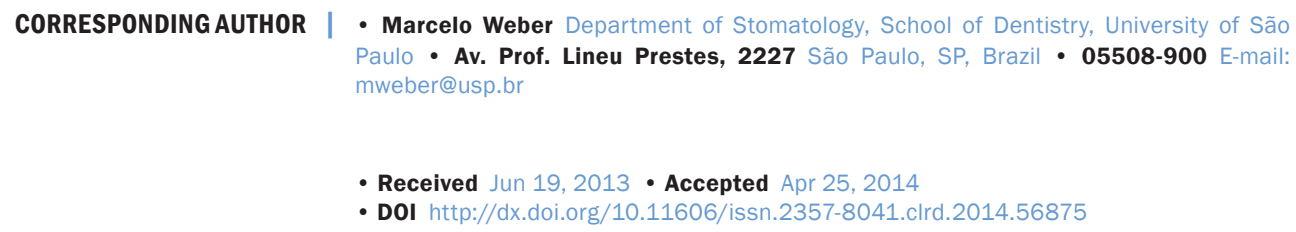




\section{INTRODUCTION}

Dental porcelains have been described as the preferred material for the substitution or repair of dental tissue owing to their color and esthetic stability.

Dental porcelains, although esthetic, are susceptible to fracture, which means they require a strong metal or porcelain framework to resist masticatory forces. ${ }^{1}$

Although color stability during the firing of porcelain onto metal has been studied, few studies have focused on the influence of the firing process on the color and translucency of aluminized porcelains owing to their recent development and use. ${ }^{1}$

There are currently many commercial brands of dental porcelains for use over alumina copings in the market. These porcelains are applied in layers, through a technique called stratification. Stratification allows the application of layers with different colors and translucencies, just like natural teeth, requiring repeated firings, for characterization and for size and color corrections. However, dentists and prosthesis technicians have empirically observed that these repeated firings somehow change the color of porcelains.

Spectrophotometric analysis is $45 \%$ more accurate than visual analysis for color measurement and for the manufacturing of porcelain-fused-tometal crowns. ${ }^{2}$

This study evaluated the color stability of three commercial brands of aluminized porcelains applied onto alumina copings, by means of a spectrophotometric analysis after repeated firings, as is the case in stratification and correction firings.

\section{MATERIALS AND METHODS}

The following commercial brands were selected for this experiment:

- Noritake Cerabien CZR (Noritake Kizai Co, Nishi-Ku, Nagoya, Japan), dentin A2, lot OE903

- VITAVM7 (VITA Zahnfabrik, Bad Säckingen, Germany), dentin 2M2, lot 7633
- AllCeram (DeguDent GmbH, Hanau, Wolfgang, Germany), dentin A2, lot 25796

Different lots of the same commercial brand may have different colors; ${ }^{3}$ therefore, all the samples of each brand were produced with powder from the same lot.

Two procedures were performed in a Ney Centurion VPC oven (Dentsply, Burlington, NJ, USA) prior to porcelain firings:

- one to decontaminate it and

- another to determinate its real temperature.

Pure silver was used to determinate the temperature, as recommended by the manufacturer. A silver lamina was burnt at a temperature of $940^{\circ}$, and the process was observed through the oven window. It was observed that the silver started to fuse at $920^{\circ}$, not at $940^{\circ}$, so all the porcelain firings were performed discounting $20^{\circ}$, as recommended by the oven manufacturer.

A firing at program no. o was performed to promote oven decontamination, in order to eliminate any oxides present.

Ten disc-shaped test specimens (TS) of each commercial brand were fabricated, measuring $10 \mathrm{~mm}$ in circumference and $2 \mathrm{~mm}$ in thickness, the size corresponding to the size of the spectrophotometer window.

The TSs were placed in individual plastic boxes numbered from 1 to 10 and labeled with their corresponding commercial brand.

The discs were fabricated first by producing black Teflon round templates, with an internal fissure of $12 \mathrm{~mm}$ in diameter by $3 \mathrm{~mm}$ in thickness, to compensate for firing contraction, thus producing final samples of $10 \mathrm{~mm}$ in diameter by $2 \mathrm{~mm}$ in thickness. The black Teflon templates were divided into two parts so that the compensated porcelain could be removed without cracking. Metal rings were produced around the Teflon templates to hold 

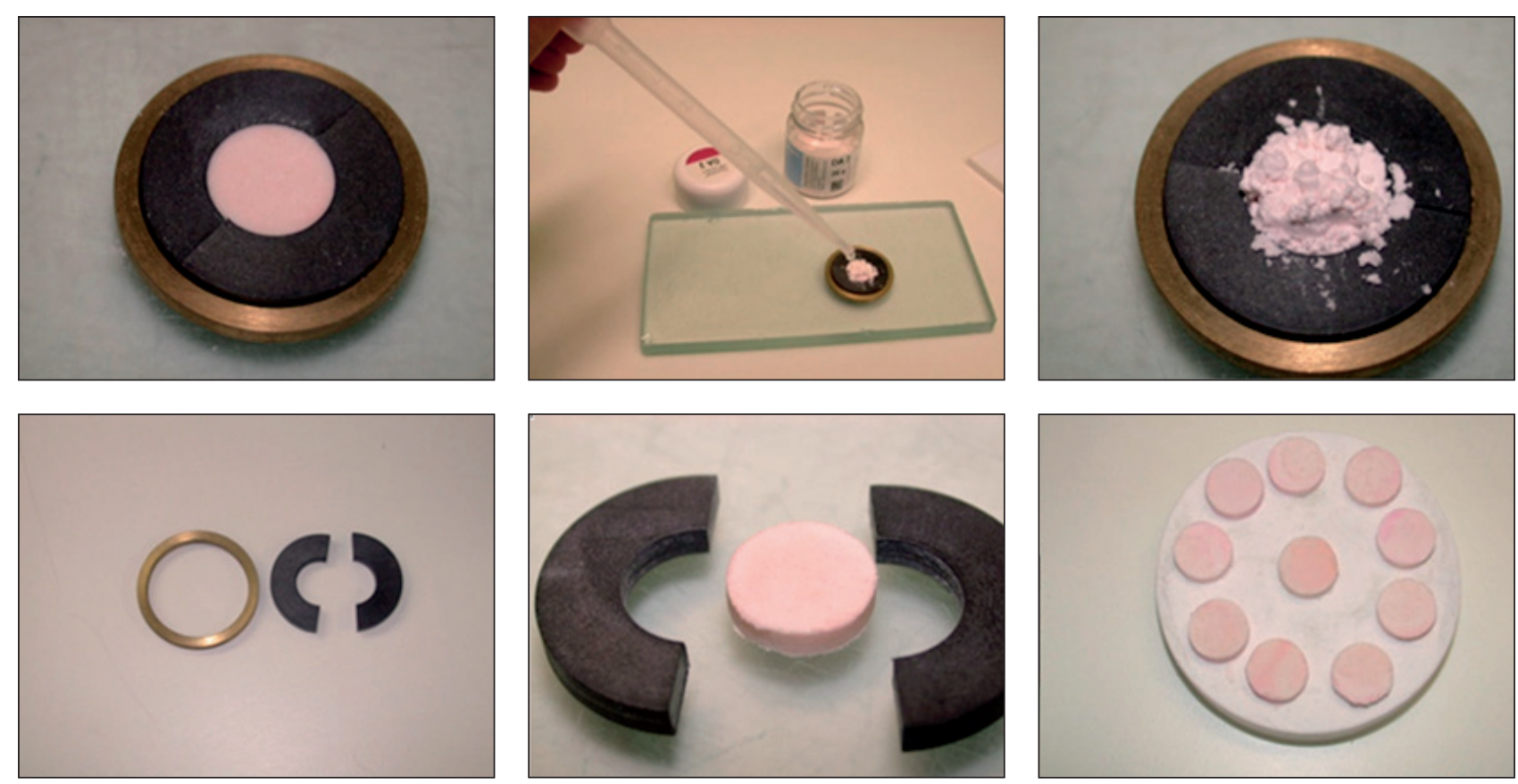

Figure 1 | Fabrication of $3 \mathrm{~mm}$ discs of porcelain to be fired.

them together during porcelain condensation.

Porcelain powders were condensed inside the templates and 3 drops of distilled water were added to each sample to facilitate condensation and removal of the porcelain from the inside of the templates without cracking (Figure 1). The samples were assembled on a glass plate and, after template removal, they were moved to a glass fiber holder and then taken to the porcelain oven to be fired according to the manufacturer's instructions.

After fabricating the porcelain discs, they were placed on the refractory holder and taken to the oven for the first dentin firing, following the recommendations of each manufacturer.

After the first firing, the thickness of the discs was measured at their center with a micrometer (Otto, São Paulo, SP, Brazil) and any samples less than $2 \mathrm{~mm}$ thick were eliminated. The samples were then cut by a buffing machine with circular sand paper at a rotation of 80 rpm under abundant flowing water. Measurements were constantly made during cutting using digital calipers (Mitu- toyo, Suzano, SP, Brazil) until reaching $2 \mathrm{~mm}$ in thickness. The samples were then cleaned in an ultrasonic bowl with distilled water for 15 minutes in order to remove impurities (Figure 2).

The samples were placed individually into numbered plastic boxes from V1 to V10 for the VITA samples, N1 to N10 for the Noritake samples, and A1 to A1o for the AllCeram samples (Figure 2).

Color analysis of each TS was performed using a Shimadzu UV-2401PC spectrophotometer (Shimadzu Corp., Kyoto, Japan) with which the reflection curve for an average daylight (D65) illumination and an observer at $2^{\circ}$ was obtained. The $\mathrm{x}, \mathrm{y}$ and $\mathrm{z}$ coordinates of chromaticity recommended by the Comission Internationale d'Eclairage (CIE1976) were taken from the reflection spectrophotometric curve, thus obtaining the LAB color-space. The " $\mathrm{L}^{*}$," "a*" and " $\mathrm{b}$ " " values were obtained according to the norms. ${ }^{4}$

For the color intervals, $\mathrm{L}^{*}$ indicates luminosity and $\mathrm{a}^{*}$ and $\mathrm{b}^{*}$ indicate color direction, where $+\mathrm{a}^{*}$ is the red direction and $-\mathrm{a}^{*}$ is the green direction, $+\mathrm{b}^{*}$ 

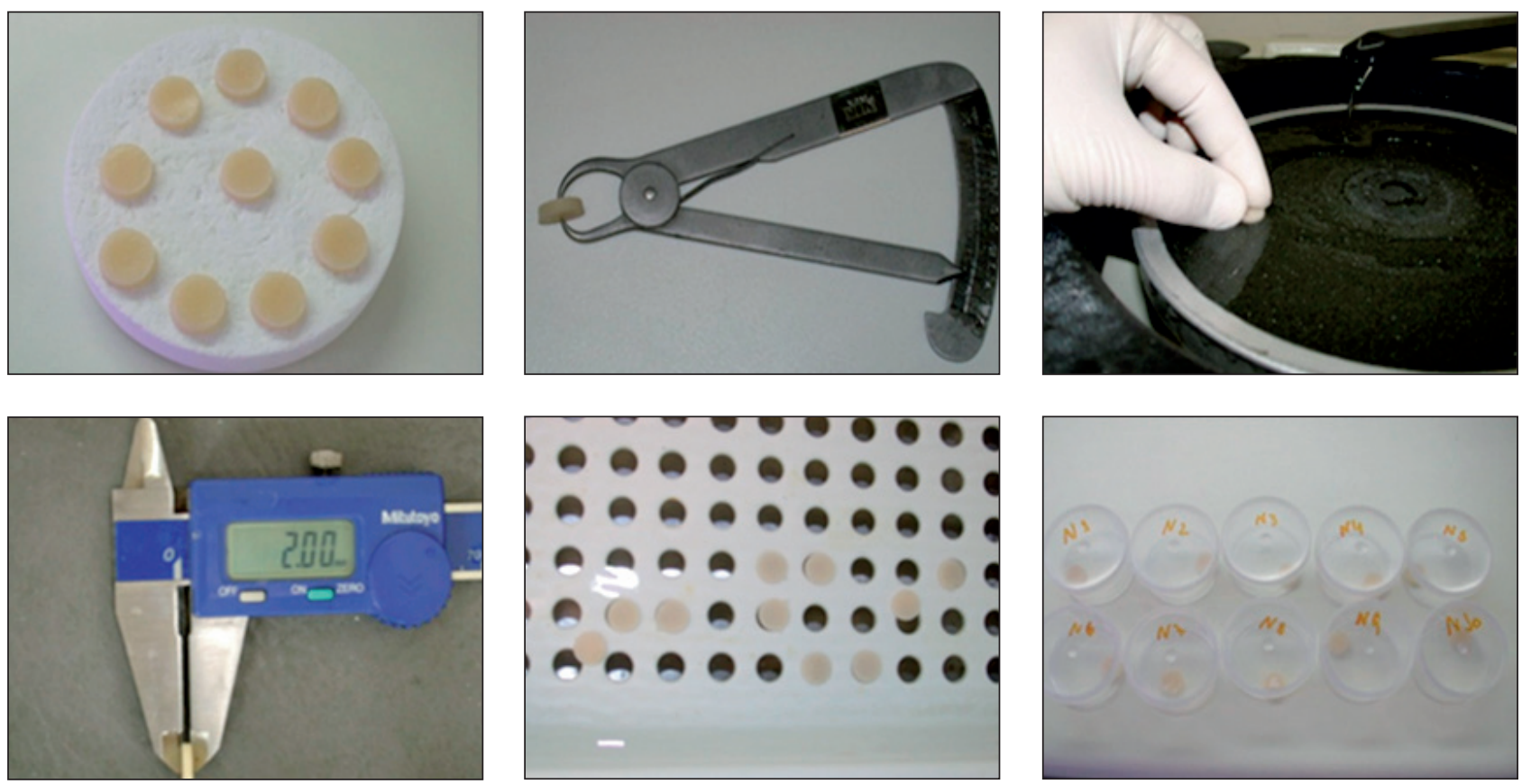

Figure 2 | Procedures to obtain a $2 \mathrm{~mm}$ sample free of dust.

indicates the yellow direction and $-\mathrm{b}^{*}$ indicates the blue direction. The center has no color.

In this study, color intervals were recorded after the $1^{\text {st }}$ firing, after the $3^{\text {rd }}$ firing, after the $5^{\text {th }}$ firing and after the $10^{\text {th }}$ firing.

The following formulas recommended by the CIE LAB method were used to measure the color differences observed after repeated firings:

$$
\begin{aligned}
& \Delta E=\left[(\Delta L)^{2}+(\Delta a)^{2}+(\Delta b)^{2}\right] 1 / 2 \\
& \Delta L=L 1-L o(\text { final }- \text { initial record) } \\
& \Delta a=a 1-a o(\text { final }- \text { initial record }) \\
& \Delta b=b 1-b o \text { (final }- \text { initial record) }
\end{aligned}
$$

Only visible light (400 to $700 \mathrm{~nm}$ ) is of interest, and human eyes are more sensitive to a wave length of about $550 \mathrm{~nm} .^{5}$

After the TSs were manufactured and cleaned, they were taken to the spectrophotometer for the first recording in the 400 to $700 \mathrm{~nm}$ light zone, and the spectrophotometric curves at intervals of $0.5 \mathrm{~nm}$ were obtained and recorded.

The samples were grouped again in the holder for firing in the oven, following the 1 to 10 sequence, and two more firings were performed, following the instructions of each manufacturer for the $2^{\text {nd }}$ dentin firing. A new spectrophotometric recording was taken of each sample. The samples were grouped again in the holder for firing in the oven, following the 1 to 10 sequence and 2 more firings were performed, following the instructions of each manufacturer for the $3^{\text {rd }}$ dentin firing. A new spectrophotometric recording was taken of each sample; the CIE LAB values were obtained and recorded.

The samples were grouped again in the holder for firing in the oven, following the 1 to 10 sequence and 5 more firings were performed, following the instructions of each manufacturer for the $4^{\text {th }}$ dentin firing. A new spectrophotometric recording was taken of each sample; the CIE LAB values were obtained and recorded. 
The color difference among the samples was calculated using the CIELAB method, and named $\Delta \mathrm{E}$. The $\Delta \mathrm{E}$ value is obtained by calculating the square root of the sum of the squares of the values of $\Delta \mathrm{L}$, $\Delta \mathrm{a}$ and $\Delta \mathrm{b}$. The $\Delta \mathrm{E}$ value for each sample was calculated between the first and the third firings, $\Delta \mathrm{E} 1$; between the third and the fifth firings, $\Delta \mathrm{E} 2$; and between the fifth and the tenth firings, $\Delta \mathrm{E}_{3}$.

\section{RESULTS}

The data obtained from the spectrophotometric recordings (Figure 3) were submitted to one-way ANOVA at a level of significance of 0.05. When the $\mathrm{p}$ value $<0.05$, the null hypothesis is rejected and the mean values are statistically different, which means at least one of the mean values is different from the others. Bonferroni and Tukey tests were applied.

There were no statistically significant differences among the $\Delta \mathrm{E} 1$ values of the Noritake Cerabien CZR, VitaVM7 and AllCeram all-ceramic systems.

However, the $\Delta \mathrm{E} 2$ mean value of the AllCeram porcelain was significantly higher than that of Noritake Cerabien CZR and VitaVM7 ( $p=9.97533)$.

There was no statistically significant difference between the $\Delta \mathrm{E}_{3}$ mean values of the three commercial brands.

At a significance level of 0.05, there was no statistically significant difference between the $\Delta \mathrm{E} 2$ means of the Noritake Cerabien CZR and VitaVM7 all-ceramic systems.

The color differences of Noritake Cerabien CZR and AllCeram were calculated after the $3^{\text {rd }}$ firing because both should show the same color, i.e. A2. The mean $\Delta \mathrm{E}$ value between the two brands was 3.8.

\section{DISCUSSION}

A $\Delta \mathrm{E}$ value below 1 is hardly visible. $\mathrm{A} \Delta \mathrm{E}$ value between 1 and 2 may be clinically visible by some observers, and a $\Delta \mathrm{E}$ value above 2 can be identified $100 \%$ of the time. A $\Delta \mathrm{E}$ value above 3.3 is not clini-

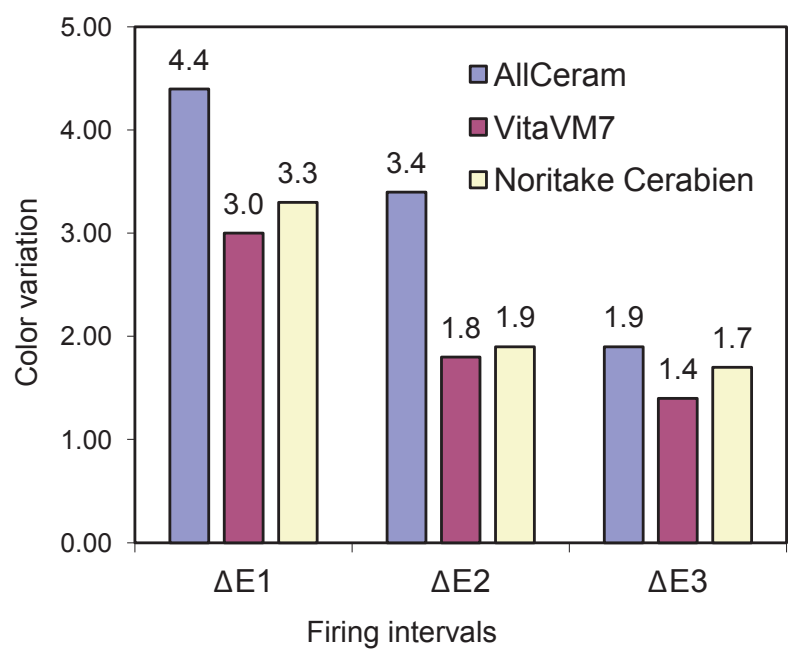

Figure 3 | Color variation of the three porcelain brands.

cally acceptable. ${ }^{2,6}$

Observing Figure 3, we can see that the $\Delta \mathrm{E} 1$ values of the VitaVM7 and Noritake Cerabien CZR samples were noticeable, but clinically acceptable, while the $\Delta \mathrm{E} 1$ of AllCeram was noticeable and not clinically acceptable. The mean $\Delta \mathrm{E} 2$ values of the Vita VM7 and Noritake Cerabien CZR samples were not noticeable by the ordinary observer and were clinically acceptable, whereas the mean $\Delta \mathrm{E} 2$ value of the AllCeram samples were noticeable and not clinically acceptable. The $\Delta \mathrm{E}_{3}$ values of the three commercial brands ranged between 1 and 2, which is not noticeable by the ordinary observer and is clinically acceptable.

Possible color change after repeated firings is due to the elimination of air pores from the inside of the porcelain during the firings.?

There is a microscopic decrease and change in the shape of the pores on the surface of the aluminized porcelains when there is an increase in firing time or temperature. ${ }^{8}$ The results obtained in this study confirm this, because a change in the color of the dental porcelains studied occurred together with the increase in firing time.

Translucency and color intensity of dental porcelain depend on the percentage of vitreous phase 
present in the structure. Both become more intense with the increase of the vitreous phase. The sintering phase, vitreous phase and crystalline phase influence not only translucency, but color intensity of the porcelain as well. ${ }^{1}$

Dependence on the porcelain firing conditions is clearly shown by the percentage of vitreous and sintering phases present in the micro structure of the porcelain.

By increasing the maintenance and temperature time, as well as the warming up time, a decrease in the sintering phase and an increase in the vitreous phase are observed. With an increase in the vitreous phase there is an increase in translucency and color intensity.

Our study has shown that, if firing time is increased, there is a color change in the dental porcelains tested.

Color changes happened more intensely especially between the $1^{\text {st }}$ and $3^{\text {rd }}$ firings because, after the first firing, the samples were finished with only a buffing machine, and after the $3^{\text {rd }}$ firing the test specimens appeared self glazed, showing a greater glow due to an increase in the vitreous phase and migration of glass particles to the surface. This greater surface glow and color intensity alter the quantity of reflected light and, consequently, the LAB values. It is important to observe the color change in this phase, because dental porcelains are normally tried out and adjusted before the glaze firing.

According to the instructions of the three manufactures, three firings are recommended:

- $1^{\text {st }}$ dentin firing,

- $2^{\text {nd }}$ dentin firing and

- $3^{\text {rd }}$ firing for glaze.

The number of firings varies according to the laboratory and patient; ${ }^{9}$ however, the color change that occurs from the $3^{\text {rd }}$ firing on is of special interest, because it is from this point on that the correc- tion firings take place. According to Figure 3, between the $3^{\text {rd }}$ and $5^{\text {th }}$ firings the $\Delta \mathrm{E}$ value was 3.4 for AllCeram, 1.8 for Vita VM7 and 1.9 for Noritake Cerabien CZR. The mean $\triangle \mathrm{E} 2$ value of the AllCeram samples was statistically higher than that of the Vita VM7 and Noritake Cerabien CZR samples. Considering the recommendations of the AllCeram manufacturer, corrections from the $3^{\text {rd }}$ firing on should be made with a corrective paste, whose firing temperature is much lower than that of the $2^{\text {nd }}$ dentin firing.

The smallest color change occurred in the interval between the $5^{\text {th }}$ and the $10^{\text {th }}$ firings for the three commercial brands, with a $\Delta \mathrm{E}_{3}$ value of 1.4 for Vita VM7, 1.7 for Noritake Cerabien CZR and 1.9 for AllCeram .

Analyzing the color stability of the three commercial brands tested in this study, we can see that the $\Delta \mathrm{E} 1$ value was higher than the $\Delta \mathrm{E} 2$ value, which was higher than the $\Delta \mathrm{E} 3$ value, which means the color change decreased along with the repeated firings, indicating that porosity and color intensity changed more markedly during the first firings.

$\Delta \mathrm{E}$ values vary according to the commercial brand tested. ${ }^{10}$ Each commercial brand in this study had its own $\Delta \mathrm{E}$ value in the firing intervals tested. However, statistically, the AllCeram porcelain had a greater color change than the Noritake and Vita VM7 porcelains in the interval between the $3^{\text {rd }}$ and $5^{\text {th }}$ firings.

A spectrophotometric analysis of the color differences among the dental porcelain systems showed that equivalent shades of different commercial brands have visible color differences. ${ }^{11}$ We agree with the authors, for the reason that, when comparing the color of the AllCeram and Noritake Cerabien CZR A2 dentin porcelains, after the standard number of three firings, we observed a $\Delta \mathrm{E}$ color difference of 3.8 , which is a visible value for the ordinary observer and not clinically acceptable.

After testing the color stability of the three com- 
mercial brands after repeated firings, by means of spectrophotometry, we have come to the conclusion that there is a clinically acceptable color variation

\section{REFERENCES}

1. Claus H. The structure and microstructure of dental porcelain in relationship to the firing conditions. Int J Prosthodont. 1989 Jul-Aug;2(4):376-84.

2. Paul SJ, Peter A, Rodoni L, Pietrobon N. Conventional visual vs spectrophotometric shade taking for porcelain-fused-tometal crowns: a clinical comparison. Int J Periodontics Restorative Dent. 2004 Jun;24(3):222-31. doi: 10.1016/j.prosdent.2004.07.004.

3. Rinke S, Huls A, Kettler MJ. Colorimetric analysis as a means of quality control for dental ceramic materials. Eur J Prosthodont Restor Dent. 1996 Sep;4(3):105-10.

4. McLaren K. M. The development of the CIE $1976\left(\mathrm{~L}^{*} \mathrm{a}^{*} \mathrm{~b}^{*}\right)$ uniform colour-space and colour-difference formula. J Soc Dyers Colour. 1976 Sep;92(9):338-41. doi: 10.1111/j.1478-4408.1976. tbo3301.x.

5. Southan DE. Factors affecting the translucency of dental porcelain. Quintessence Int. 1987 Mar;18(3):197-202.

6. Ruyter IE, Nilner K, Moller B. Color stability of dental composite resin materials for crown and bridge veneers. and that this variation depends on the number of firings performed and on the commercial brand used.

Dent Mater. 1987 Oct;3(5):246-51. doi: 10.1016/So1095641(87)80081-7.

7. Barghi N, Goldberg. Porcelain shade stability after repeated firing. J Prosthet Dent. 1977 Feb;37(2):173-5. doi: http:// dx.doi.org/10.1016/0022-3913(77)90239-6.

8. Cheung KC, Darvell BW. Sintering of dental porcelain: effect of time and temperature on appearance and porosity. Dent Mater. 2002 Mar;18(2):163-73. doi: doi:10.1016/so1095641(01)00038-o.

9. Seghi RR, Johnston WM, O'Brien WJ. Spectrophotometric analysis of color differences between porcelain systems. J Prosthet Dent. 1986 Jul;56(1):35-40. doi: 10.1016/o0223913(86)90279-9.

10. O’Brien WJ, Kay KS, Boenke KM, Groh CL. Sources of color variation on firing porcelain. Dent Mater. $1991 \mathrm{Jul} ; 7(3): 170-3$. doi: 10.1016/0109-5641(91)90038-Z.

11. Seghi RR, Hewlett ER, Kim J. Visual and instrumental colorimetric assessments of small color differences on translucent dental porcelain. J Dent Res. 1989 Dec;68(2):1760-4. 10.1177/00220345890680120801. 